OPEN ACCESS

UWS Academic Portal

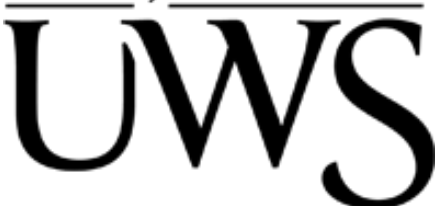

\title{
Corporate social responsibility reporting of international oil companies in Nigeria
}

Odera, Odhiambo; James, Kieran; Scott, Albert; Gow, Jeff

Published in:

International Journal of Ethics and Systems

DOI:

10.1108/IJOES-04-2019-0071

Published: 02/01/2020

Document Version

Peer reviewed version

Link to publication on the UWS Academic Portal

Citation for published version (APA):

Odera, O., James, K., Scott, A., \& Gow, J. (2020). Corporate social responsibility reporting of international oil companies in Nigeria: an historical materialism analysis. International Journal of Ethics and Systems, 36(1), 131146. https://doi.org/10.1108/IJOES-04-2019-0071

\section{General rights}

Copyright and moral rights for the publications made accessible in the UWS Academic Portal are retained by the authors and/or other copyright owners and it is a condition of accessing publications that users recognise and abide by the legal requirements associated with these rights.

Take down policy

If you believe that this document breaches copyright please contact pure@uws.ac.uk providing details, and we will remove access to the work immediately and investigate your claim. 


\title{
Corporate Social Responsibility Reporting of International Oil Companies in Nigeria: An Historical Materialism Analysis
}

\author{
Odhiambo Odera* \\ Gretsa University, Thika, Kenya \\ Kieran James \\ University of the West of Scotland, Paisley Campus, Scotland \\ Albert Scott \\ Lecturer, School of Commerce, University of Southern Queensland, Toowoomba, Australia \\ Jeff Gow \\ Professor, School of Commerce, University of Southern Queensland, Toowoomba, Australia and \\ Professor Extraordinary, Department of Agriculture Economics, Stellenbosch University, \\ Stellenbosch, South Africa
}




\section{Abstract}

Purpose -This study aims to identify factors influencing Corporate Social Responsibility Reporting (CSRR) practices of International Oil Companies (IOCs) in Nigeria. It aims at distinguishing CSRR levels by examining both the quantity and quality of reporting.

Design/methodology/approach - The paper analyses annual reports through content analysis. CSRR extent and type are measured by the number of sentences. CSRR are further classified into three subcategories according to whether they are negative, neutral or positive reports and then their proportions compared through descriptive analysis.

Findings -For the extent and quality of CSRR, community was the most reported category. The majority of the total CSRR in the IOCs is positive with little evidence of negative news. None of the IOCs in the sample reported on the environment in their annual reports.

Research limitations/implications - The measurement of CSRR focuses only on annual reports, without consideration of other reporting media such as standalone reports and corporate websites. CSRR are assumed to be voluntary for the companies and they may choose not to report any information in annual reports, as there are no regulations or reporting guidelines in Nigeria to be followed.

Practical implications -The results reveal the absence of environmental reporting in the CSRR of IOCs in Nigeria suggests that they less concerned with meeting local demands for accountability. The study recommends the need for regulatory intervention on the part of the Nigerian Government.

Social implications -The findings of study indicate that predominant existence of positive CSRR news among all the IOCs suggests there's an attempt to encourage stakeholders and the public to believe that they are conscious of society and the environment.

Originality/value -The main contribution of this study lies in identifying the factors that have led to diversity and uniqueness in CSRR in IOCs. As such, this study seeks to contribute to the development of understanding multiple factors that could give rise to changing patterns of CSRR.

Keywords: Nigeria, International oil companies, corporate social responsibility reporting, Business ethics, Sustainability, Historical materialism theory.

\section{Introduction}

Corporate Social Responsibility Reporting (CSRR) has received increasing attention as companies recognise that their actions have consequences that affect stakeholders. CSRR has gained significant prominence in the business world over the past few decades (Singh et al., 
2017). Some attention has been given to analysing what and how companies report on particular issues and the quality of that reporting (Odera et al., 2016). As organisations respond to the increasing concerns about social and environmental issues by producing CSRR, a lack of standardized reporting and an ambiguity in interpretation of the reports results in consistency of their disclosures (Ong, 2016). The voluntary nature of CSSR and the lack of a single, generally recognized standard according to which these reports can be developed, are the reasons for the differences occurring in the content and quality of these reports (Habek \& Wolniak, 2016).

A considerable amount of literature has been published on CSRR (Hooks \& Van Staden, 2011; Islam et al., 2011; Kamal \& Deegan, 2013; Narwal \& Singh, 2013; Sen et al., 2011; Shayuti, 2012). Cowan \& Gadenne (2005) provided evidence that differences in CSRR behaviours occur within voluntary environments, for example, companies adopt different approaches when the reporting are under increased scrutiny. Some reasons that have been advanced to justify CSRR of international companies are: (1) CSRR may help a company to improve its image and promote goodwill and (2) companies may resort to CSRR in an attempt to improve their reputation and erase the negative effects caused by environmental accidents (Abdo \& Aldrugi, 2012).

It can be argued that because of their geographical extension, international companies are more likely to face greater social pressures. Blanc et al. (2017) state that the higher levels of social and political pressure lead companies to use CSRR as a means of reducing their exposures. Some types of social pressures that international companies face include but are not limited to: peaceful and/or violent protests; criticisms and exposure by media; pressure from non-governmental organisations (NGOs); employee strikes; community demonstrations; and boycott of products (Islam, 2015).

International oil companies (IOCs) have faced numerous violent protests from their host communities as a sign of discontent with their operations mainly in developing countries where they blatantly disregard the social and environmental impacts. The paper is motivated by the need to study how IOCs attempt to cultivate more supportive communities, enhance their credibility and avoid potential reputation risk through the release of CSRR. According to Idowu \& Towler (2004), some motivations for CSRR include more supportive communities and the 
avoidance of potential reputation risks which may arise from environmental incidents. Kolk (2004) asserts that societal aspects such as credibility and reputation have been found important as reasons for undertaking CSRR. Idowu \& Papasolomou (2007) found that companies tend to employ reporting practices because it is necessary to meet stakeholder's requirements.

The topic is about identifying factors influencing CSRR practices of IOCs in Nigeria. Companies recognise through CSRR that their actions have consequences that affect stakeholders. Companies tend respond to the increasing concerns about social and environmental issues by producing CSRR. The topic is important since IOCs have been accused of not acknowledging the effects of their operations on social and environmental adverse impacts against their host communities resulting from frequent oil spills, gas flaring, non remediation and non compensation.

Few studies have been conducted regarding CSRR of IOCs. Cunha \& Moneva (2016) analyzed the CSRR practices of 40 companies from the global oil sector and revealed that the level of assurance of CSRR reports in most companies is low. Eljayash et al. (2013) conducted a comparative study between IOCs and national oil companies CSRR in the Arab petroleum exporting countries and found that CSRR by word count had increased during the period study. Abdo \& Al-Drugi (2012) investigated CSRR practices by local and IOCs operating in Libya and found that more attention was paid to reporting of good news. As a result, due to a lack of adequate research relating to CSRR in annual reports IOCs, operating in developing countries such as Nigeria, further investigation is required.

This paper seeks to contribute to the understanding of IOCs responses to the demands and changes in the CSRR by identifying the factors that lead to the uniqueness in CSRR practices of IOCs in Nigeria. As such, this study seeks to contribute to the development of understanding multiple factors that could give rise to the changing patterns of CSRR. Additionally, it will serve as a benchmark of current CSRR practices for IOCs to consider improving the nature and type of their CSR reports. Furthermore, it is the first study to use Historical Materialism Theory in the context of CSRR. 


\section{Literature review}

Since the early 1990s, there has been a growing interest in CSRR as one of the most important types of accounting reporting (Islam et al., 2005). Adnan et al. (2010) state that the influence of the country of origin drives CSSR, concluding that organizations in emerging markets may prefer to discuss economic performance rather than sustainability performance, even in reporting. Organizations that operate in a foreign country may copy CSSR practices that are prevalent in that foreign country as they may want to access certain benefits by emulating or mimicking their reporting practices (Nwobu, 2017). It could be argued that the very nature of internationalisation, by companies of any nationality, leads to an increase in CSRR (Odera et al., 2016).

The relationship between foreign presence of a company and CSRR suggests that as companies expand their operations to foreign environments, there is tendency for them to incorporate developments that have been institutionalized in those environments (Nwobu, 2017). Beddewela \& Herzig (2013) found that Sri Lankan subsidiaries' of multinationals disclosure behaviour (i.e. an absence of local CSRR reports) were primarily motivated by the need to attain internal legitimacy (to the global headquarters) and less about providing accountability to local stakeholders. Abdo \& Aldrugi (2012) state that differences in the nature of the CSRR depends on the company's country of ultimate ownership. Alternatively, it could be argued that the very nature of internationalisation, by companies of any nationality, leads to an increase in CSRR (Odera et al., 2016). Country context and type of industry have an impact on their reports in terms of their CSRR styles (Islam et al., 2011). Several studies suggest that it is mainly the economically powerful stakeholders from overseas (e.g. multinationals and foreign investors) who are the "relevant publics" being "targeted" rather than the local stakeholders (Buccina et al., 2013; Belal et al., 2013). In this regard, CSSR are seen to be less concerned with meeting local demands for accountability and more inspired with impression management features such as a rhetorical manipulation aimed at the sophisticated audience located in their country of origin (Soobaroyen \& Ntim, 2013).

Hilson (2012) notes that the implied message is that CSR standards and programs formulated and implemented by MNCs in developed countries where they are headquartered are also adopted at their operations in the developing countries where they work. Jamali \& Karam (2018) state that 
there are more global geopolitical relations that spillover to shape local relations in the context of CSR. Various scholars note how CSR activities in developing countries are simultaneously shaped by the expectations of the global community (e.g. Gugler \& Shi, 2009; Islam \& Deegan, 2008).

Nearly all Fortune 500 companies report their CSR activities on their websites (Smith \& Alexander, 2013). The terms "Community" and "Environment" were found to clearly be the most popular headings on company websites. By analyzing the CSRR of the Fortune 500 companies, Legendre \& Coderre (2013) discovered that company size, the business culture of a country and type of industry significantly influence adoption of the GRI G3 guidelines. Cho et al. (2015) show that Fortune 500 companies manipulate CSRR to emphasize good news and rhetorically deflect or rationalize poor social and environmental performance. Similarly, Patten (1992) found a significant increase in CSRR by 21 petroleum companies listed in the Fortune 500 the after the Alaskan oil spill incident.

Ali \& Rizwan (2013) cite subsidiaries of multinational companies as experiencing indirect pressure to adopt best practices from their parent company. Multinational subsidiaries face internal legitimacy threat from parent companies, thus forcing them to imitate their parent companies (Momin \& Parker, 2013). Since parent international companies may be located in developed countries where CSRR are relatively high, related companies are likely to adopt these best practices (Welbeck, 2017). Other empirical studies have shown mixed results on the effect of parent companies on subsidiaries (Momin \& Parker, 2013). However, Welbeck (2017) suggests that foreign associated companies influence their subsidiaries significantly and monitor their CSSR practices through establishment of systems and structures that can enhance social and environmental reporting.

A number of studies have been undertaken with respect to CSSR in countries other than Nigeria (Gherardi et al., 2014; Peters \& Romi, 2015; Thoradeniya et al., 2015). CSSR developments in developing countries appear to be primarily inspired and influenced by international pressures (Soobaroyen \& Mahadeo, 2016). Asaolu et al. (2011) found that unlike their foreign affiliated counterparts, multinational oil and gas companies operating in Nigeria do not report on some 
aspects of CSRR. While many studies have investigated the CSRR practices by companies in their annual reports in Nigeria, only a few studies have emerged that actually detail the state of CSRR of IOCs.

\section{Theoretical Framework: Historical Materialism Theory}

Historical Materialism Theory (HMT) is an attempt to explain the origin and development of the society from a materialistic perspective. HMT takes as its starting point the view that, before anything else, human beings must satisfy their everyday economic needs through their physical labour and practical activities (Marx \& Engels, 1970). HMT states that material realities and the way humans transform material realities (i.e. modes of production) are functionally connected to how culture and social norms play out in the human sphere (Levine \& Sober, 1985).

According to Hartviksen (2014), HMT contends that the processes of capital accumulation help shape, and in turn are shaped by, class relations in society. The main purpose of the capitalist society remains to be profit maximization or capital accumulation (Akbas, 2012). However, it is better to understand social movements in terms of their relationship to capital accumulation (Bebbington et al., 2008). Harvey (2003) identifies two distinct types of "accumulation by exploitation" and "accumulation by dispossession". The capitalist relations continue to exist where a certain level of capital accumulation is a necessary condition for the capitalist class to continue to be dominant (Lash \& Urry, 1987).

HMT points to economics as a key factor that influences most aspects of society, including how businesses are conducted (Keshishian, 2015). Through the use of HMT, this study hopes to illuminate CSRR role in the exploitative nature of the capitalistic mode of production. HMT lens will be used to reveal connections between community involvement and development, and capital accumulation. The justification for applying HMT is that it does more than simply explain the provision of information to shareholders; it explains how the demands for CSRR seek to reduce levels of exploitation by informing the host communities. HMT was preferred, as its supports the view that whilst organisations have the ability to control the amount of information released, CSRR must include the achievement, maintenance or restoration of public perceptions of the organisation. 


\section{Methodology}

\section{Content analysis}

Content analysis has been extensively used in examining CSRR practices (see for example Kamal \& Deegan, 2013; Novelini \& Fregonesi, 2013; Pesci \& Costa, 2014; Rahma \& Anis, 2013; Talebnia et al., 2013; Van de Burgwal \& Vieira, 2014). Content analysis refers to the process of making inferences based on objective coding of information. One of the major strengths of this type of analysis is its generalizability given that it uses voluminous numerical data to establish significant relationships (Odera et al., 2016). Annual reports were chosen to measure CSRR since they are formal public documents produced by companies and are the most accessible source of information for listed companies. Fu et al. (2012) argue that annual reports are accorded a substantial degree of prominence and attention. Five CSRR categories comprising: community, health \& safety, employee, corporate governance and environment were identified as a consistent measurement method.

The research method that has been commonly used in literature to measure the CSRR quantity is content analysis (Hassan, 2014). CSRR extent and type were measured by the number of sentences. The measurement in terms of sentences was justified in that: (1) sentences were counted with more accuracy than words; and (2) sentences were used to convey meaning whereas discerning the meaning of individual words in isolation was problematic (Hackston \& Milne, 1996). The number of sentences is chosen as it is easily identified and allows for a more refined examination of reporting (Mbekomize \& Wally-Dima, 2013).

CSRR was further classified into three subcategories according to whether they were negative, neutral or positive reports and then their proportions were compared through descriptive analysis. Mitchell et al. (2006) classified CSRR as positive, negative or uncertain/neutral based. Positive reports are defined as information where the company is presented as operating in harmony with the society/environment. Neutral reports are defined as when CSRR is given but the impact is unclear. Negative reports are defined as those 'that present the company as operating to the detriment of the society/environment'. The role of this classification is to capture variation in CSRR content and is based on the social and environmental issues reported (Plumlee et al., 2010). 
Measuring CSRR quantity only was not adequate for understanding Corporate Social Responsibility (CSR) information; hence, reporting quality was also taken into account. CSRR quality refers to whether the reports are on specific actions, quantifies social and environmental impacts, sets formal targets and are subject to external audit. CSRR quality was determined according to whether reports provided clear and specific information (Hassan, 2010). Content analysis is the main technique in interpretative analysis for measuring CSRR quality (Ashwin, 2011). The common method for measuring CSRR quality is rank information, according to predetermined factors. Various ranking systems have been used in the literature to measure CSRR quality. These ranking systems present different point scales for assessing quality. Cormier et al. (2005) suggested a three-point scale system, while Van Staden \& Hooks (2007) developed a five-point scale to assess CSRR quality.

\section{Data}

Three oil companies listed on the Nigerian Stock Exchange as well as an additional three nonlisted major IOCs (Shell, Chevron and Agip) were selected for analysis, because of the scale of their operations in the Niger Delta. The study adopted James (2011) classification of IOCs as companies that have their objective as the profit maximization for their shareholders through oil and gas extraction. IOCs headquarters generally tend not to be based in the countries in which the majority of their extraction operations are located. Table 1 illustrates the sample of 6 IOCs selected for the study.

\section{Table 1: The sample of IOCs in Nigeria}

\begin{tabular}{|l|}
\hline \multicolumn{1}{|c|}{ International Oil Companies } \\
\hline Total Nigeria Plc. \\
\hline Mobil Oil Nigeria Plc. \\
\hline Shell Petroleum Development \\
Company of Nigeria Ltd (SPDC) \\
\hline Nigeria Agip Oil Company Ltd \\
\hline Chevron Nigeria Ltd \\
\hline MRS Oil Nigeria Plc. \\
\hline
\end{tabular}

The study examined annual reports over a 20 year period from $1^{\text {st }}$ January, 1992 to $31^{\text {st }}$ December, 2011. It has been noted that CSRR data are not comparable either within a report, 
between reports of different years, or between reports from different companies even within the same sector (Jenkins \& Yakovleva, 2006). The annual reports were sourced through direct request from the companies, by visiting the Nigeria Stock Exchange (NSE) and through the Securities and Exchange Commission (SEC) located in Lagos during the period January February, 2013. All analyses were performed using SPSS for Windows Version 22 software.

\section{Results}

\section{Corporate social responsibility reporting quantity analysis}

The measurement of CSRR in annual reports requires a clear definition for CSRR categories. Five CSRR categories comprising community, health \& safety, employee, corporate governance and environment are identified as a consistent measurement method.

Table 2: Summary of CSRR in annual reports

\begin{tabular}{|l|l|l|}
\hline & \multicolumn{2}{|c|}{ Sentences } \\
\hline Characteristics & No. $^{\mathrm{a}}$ & $(\%)^{\mathrm{b}}$ \\
\hline Categories & & \\
\hline Employee & 571 & 34.90 \\
\hline Environment & 0 & 0 \\
\hline Community & 707 & 43.22 \\
\hline Health \& safety & 242 & 14.79 \\
\hline Corporate governance & 116 & 7.09 \\
\hline Total & 1636 & 100 \\
\hline
\end{tabular}

Notes: a Number of sentences incorporating CSRR, that is, amount of reporting; ${ }^{\text {bnumber of sentences }}$ incorporating the given type of CSRR as a percentage of all sentences incorporating reporting (1,636 sentences).

Table 2 summarizes the results of the content analysis. The total number of CSRR sentences by categories was 1,636 . The most reporting was on community involvement and development with 707 (43.22 per cent) sentences, followed by employee-related information at 571 (34.90 per cent) sentences, health \& safety with 242 (14.79 per cent) sentences, corporate governance with 116 (7.09 per cent) sentences and lastly there was no reporting on the environment with 0 ( 0 per cent) sentences. The results reveal that prominence given to community involvement and development was consistent with previous studies found in other countries. Jitaree (2015) found that Thai companies are more likely to disclose CSRR regarding community and employee information. 
Djajadikerta \& Trireksani (2012) reveal that the most reported information in corporate websites of Indonesian companies listed in the Indonesian Stock Exchange (IDX) was community.

Perhaps the most striking finding was the lack of environmental reports, which is consistent with Uwalomwa \& Jimoh (2012) who observed that environmental reports among the selected listed companies in Nigeria was relatively low. Sahore \& Verma (2017) revealed the prevalence of a general lack of emphasis on environmental reports in Indian companies. The data presented here indicate that environmental issues are not regarded as being central in CSRR.

Table 3: Descriptive statistics of the extent of CSRR categories in the oil companies

\begin{tabular}{|l|r|r|r|r|r|}
\hline & Employee & Environment & Community & $\begin{array}{c}\text { Health \& } \\
\text { Safety }\end{array}$ & $\begin{array}{c}\text { Corporate } \\
\text { Governance }\end{array}$ \\
\hline Mean & 15.86 & 0 & 24.37 & 10.08 & 7.73 \\
\hline Standard Deviation & 16.47 & 0 & 16.61 & 5.72 & 3.17 \\
\hline Sample Variance & 271.32 & 0 & 276.17 & 32.77 & 10.06 \\
\hline Minimum & 0 & 0 & 0 & 0 & 0 \\
\hline Maximum & 72 & 0 & 72 & 22 & 11 \\
\hline Sum & 571 & 0 & 707 & 242 & 116 \\
\hline$\%$ & 34.90 & 0 & 43.22 & 14.79 & 7.09 \\
\hline
\end{tabular}

Table 3 depicts the sentences data per CSRR categories of the oil companies. In the employeerelated information category, companies have an average of 15.86 and with no mean values for the environment category. Community involvement and development reported averages of 24.37 while health \& safety and corporate governance categories have mean values of 10.08 and 7.73 respectively. Cotter et al. (2011) argued that management will examine the costs and benefits of CSRR before making any decision on whether to report or not. However, companies can reduce the risk of potential loss from reputational damage by disclosing CSRR (Chousa et al., 2017).

Table 4: Type of CSRR categories in the oil companies

\begin{tabular}{|l|l|l|l|}
\hline CSRR Categories & Positive CSRR & Negative CSRR & Neutral CSRR \\
\hline Employee & $527(32.21 \%)$ & $7(0.44 \%)$ & $37(2.26 \%)$ \\
\hline Environment & $0(0 \%)$ & $0(0 \%)$ & $0(0 \%)$ \\
\hline Community & $696(42.54 \%)$ & $11(0.67 \%)$ & $0(0 \%)$ \\
\hline Health \& Safety & $242(14.79 \%)$ & $0(0 \%)$ & $0(0 \%)$ \\
\hline Corporate Governance & $116(7.09 \%)$ & $0(0 \%)$ & $0(0 \%)$ \\
\hline Total & $1581(96.63 \%)$ & $18(1.11 \%)$ & $37(2.26 \%)$ \\
\hline
\end{tabular}


Table 4 indicates the dominance of positive CSRR at 96.63 per cent of total reporting. These findings are consistent with the results of previous studies examining CSRR practices (Cowan \& Gadenne, 2005). Companies tend to disclose positive CSRR but report little negative impacts on their social activities (Virtania \& Siregar, 2017). Companies will sometimes use positive reports to deflect attention away from the crisis event, making no attempt to change the expectations of their relevant publics (Cho, 2009).

Table 4 further indicates that neutral reporting was 2.26 per cent and negative CSRR being the least reported at 1.11 per cent. The results are consistent with Mitchell et al. (2006) who found that the vast majority of reports are positive in nature with limited negative reports occurring since companies use CSRR in a self-promoting manner by reporting almost solely positive or at the very least neutral items.

\section{Corporate social responsibility reporting quality analysis}

The excellence of CSRR depends on both the quantity and the quality of the information provided. Consistent with Hooks \& Van Staden (2011) and Shayuti (2012), this study computed CSRR quality per sentence scores. CSRR quality in annual reports was measured using a 2-point scale system as follows: 1: if CSRR is quantitative and reports specific activities of a company concerning its social and environmental responsibility; 0: not-reported.

Table 5: Descriptive statistics of the number of quality CSRR sentences

\begin{tabular}{|l|c|c|c|c|c|}
\hline & Employee & Environment & Community & $\begin{array}{c}\text { Health \& } \\
\text { Safety }\end{array}$ & $\begin{array}{c}\text { Corporate } \\
\text { Governance }\end{array}$ \\
\hline Mean & 6.30 & 0 & 15.67 & 5.65 & 6.77 \\
\hline Standard Error & 0.76 & 0 & 1.59 & 0.80 & 0.93 \\
\hline Median & 4 & 0 & 13 & 3 & 5 \\
\hline Mode & 2 & 0 & 1 & 3 & 2 \\
\hline Standard Deviation & 6.63 & 0 & 11.13 & 5.59 & 5.55 \\
\hline Sample Variance & 43.97 & 0 & 124.01 & 31.25 & 30.88 \\
\hline Kurtosis & 11.40 & 0 & -0.50 & 5.84 & 2.49 \\
\hline Skewness & 3.06 & 0 & 0.41 & 2.29 & 1.51 \\
\hline Range & 39 & 0 & 42 & 27 & 24 \\
\hline Minimum & 0 & 0 & 0 & 0 & 0 \\
\hline Maximum & 39 & 0 & 42 & 27 & 24 \\
\hline Sum & $149(27.29 \%)$ & $0(0 \%)$ & $239(43.77 \%)$ & $84(15.39 \%)$ & $74(13.55 \%)$ \\
\hline
\end{tabular}


Of the 1,636 total number of CSRR sentences, only 546 (33.4 per cent) were considered to be of quality. Table 5 illustrates the descriptive statistics of CSRR quality of sentences by the reporting categories. The highest CSRR quality reported is in the community involvement and development category with 239 sentences and an average of 15.67. In the annual reports, the number of quality sentences of community involvement and development reports ranges from 0 to 42. The employee-related information reports category has the second highest CSRR quality sentences at 149 with a mean of 6.30 and the number of quality sentences ranges from 0 to 39 . The health \& safety reports category was ranked third with 84 quality sentences ranging from 0 to 27 and an average of 5.65 .

The corporate governance reports category is fourth with 74 quality sentences having a mean of 6.77. The number of quality sentences for corporate governance reports ranges from 0 to 24 . There were no reports in the environment CSRR category. The results indicate great variations in CSRR quality both in total and in different reporting categories.

\section{Discussion}

Firstly, the results reveal that for the extent of CSRR, community involvement and development was the most reported category at 43.22 per cent. For the quality of CSRR, the same category had the highest number of quality sentences at 43.77 per cent. The findings are consistent with other studies. For example, Branco \& Rodrigues (2006) revealed that Portuguese companies in industries with high visibility are more likely to disclose information on community involvement. Matuszak \& Różańska (2017) found that community involvement was predominantly featured in the information disclosed in Polish-listed companies. Botshabelo et al. (2017) suggested that in Botswana, the majority of banks engage extensively in and report their participation in community involvement activities. While Abukari \& Abdul-Hamid (2018) found that in Ghana, the community involvement category received much attention in their reportage, which supports earlier studies that most organizations are committed to corporate philanthropy. However, contrary to the results of this study Douglas et al. (2004) noted that community involvement was least reported. This could be reflective of the apparent contrast between the developed world and developing countries' governments in provision of social welfare support to the public. IOCs may prepare more CSRR in the community categories to 
camouflage them from not reporting on any environmental degradation (especially oil spills) as a result of their operations. Likewise, IOCs maybe attempting to create engagement with the communities through effective CSR framework in order to achieve sustainable development in host communities (Okoro, 2014).

None of the companies in the sample mentioned the word "environment" in their annual reports. These results concur with previous studies such as Al-Hamadeen \& Badran (2014) who revealed the continued weak reporting related to the environmental aspects of Jordanian Public Shareholding companies. Saleh (2009) found that reporting on the environment required much more attention from Malaysian firms. Thomson \& Zakarai (2004) observed that the corporate environmental reporting of Malaysian companies was poor both in quality and quantity. The reasons for the companies not reporting on the environment may be that CSRR may be used by the host communities against the reporting company to file a lawsuit, resulting in negative monetary implications for the company. Capitalism is a complex and contradictory system and so the information it relies upon can be used to challenge existing exploitation and oppressions (Catchpowle \& Smytha, 2016).

Secondly, the results reveal that 96.63 and 1.11 per cent of the total CSRR in the IOCs were positive and negative news, respectively. This finding is consistent with Sen et al (2011) who observed that more than 95\% of the total CSRR by Indian companies revealed positive news with no negative news being reported. Ahmad et al. (2003) found that approximately $80 \%$ of companies in Malaysia reported positive news with only 2\% negative news. Belal (2001) illustrated that CSRR of 30 Bangladesh companies largely emphasised on positive news. Uwalomwa \& Jimoh (2012) indicate that about $57 \%$ of selected manufacturing companies in Nigeria concentrated more on positive disclosures rather than negative and neutral news at $18 \%$ and 24\% respectively. Cunningham (2001) demonstrated that companies provide little negative SED even when they have experienced several negative social/environmental events. The results imply that CSRR is mainly about corporate image building and impression management. The prevalent presence of positive CSRR news creates the impression of companies that are socially and environmentally friendly. The predominant existence of positive CSRR news among all the IOCs suggests efforts to provide information that they are mindful of the society and 
environment. The concentration of positive reports reflects an attempt to encourage shareholders and the public to believe that the companies are in harmony with and are conscious of society and the environment (Mitchell et al., 2006).

HMT is underpinned by the assumption that it gives primacy to materialism in explanation of social factors. Hence, it advocates for particular attention to be paid to the economic substructure of society. IOCs have attempted to provide the type of CSRR that would fulfill their aims and objectives. As advanced by HMT, CSRR is seen as being integral to capitalism, information produced by capitalists for capitalists (Catchpowle \& Smytha, 2016). Gallhofer \& Haslam (2003) assert that historically CSRR has been mobilized to illustrate the exploitation that capitalism generates. Environmental problems can be traced directly to the exploitative dynamics of capitalism and solutions to such problems require transformation of the relations of production (Pepper, 1996).

HMT is underpinned by the assumption that it gives primacy to materialism in explanation of social factors. Hence, it advocates for particular attention to be paid to the economic substructure of society. IOCs have attempted to provide the type of CSRR that would fulfill their aims and objectives. As advanced by HMT, CSRR is seen as being integral to capitalism, information produced by capitalists for capitalists (Catchpowle \& Smytha, 2016). Gallhofer \& Haslam (2003) assert that historically CSRR has been mobilized to illustrate the exploitation that capitalism generates. Environmental problems can be traced directly to the exploitative dynamics of capitalism and solutions to such problems require transformation of the relations of production (Pepper, 1996).

This study investigates CSRR practices of IOCs in Nigeria, and adds significantly to the growing knowledge of CSR reporting in developing countries. It contributes to the understanding of companies' responses to the demands and changes in the CSRR since the beginning of the 1990s. The main contribution of this study lies in identifying the factors that have led to uniqueness in CSRR practices of IOCs in Nigeria. Furthermore, it serves as a benchmark of current CSRR practices for companies to consider improving the nature and type of their CSR reports. 


\section{Conclusions}

The purpose of this study was to identify the extent and type of CSRR in IOCs. The findings indicate that there were no environmental reports in terms of both quantity and quality. Moreover, results reveal that the majority of CSRR in IOCs were positive news. Furthermore, CSRR negative news in the IOCs was minimal. The implication of the findings suggests that if CSRR in the annual reports is left as a voluntary practice as it is currently, it is unlikely that the independence of the information will improve in IOCs of Nigeria (Odera et al., 2016). Being socially responsible leads to stronger financial performance and allows the company to establish itself in a leading position (Kanter, 2011). Firms provide information about their CSR initiatives through CSRR. A company that takes various steps to conserve the environment when making crucial business decisions should report this information to the public. Companies try to enhance their image and create good reputation by demonstrating corporate citizen behaviours.

Relying on voluntary CSRR is unlikely to result in increased levels of quantity and quality of reports and some form of regulatory intervention on the part of the Nigerian Government is recommended. The limitations of the study regards the measurement of CSRR focused only on annual reports, without consideration of other reporting media such as standalone reports and corporate websites. Second, CSRR were assumed to be voluntary for the companies, and they may choose not to report any information in annual reports because there are no regulations or reporting guidelines in Nigeria to be followed. Third, CSRR data were analysed through content analysis which has several limitations: (1) the notion that content analysis only captures the quantity of reports rather than the quality characteristics (Zunker, 2011); and (2) there is an element of subjectivity involved in determining what constitutes a particular type of report (Guthrie \& Abeysekera, 2006). Future research could investigate CSRR practices using other reporting media such as standalone reports and/or corporate websites. CSRR categories could be expanded or examined individually in future research. Future studies could likewise investigate CSRR practices of one or more IOCs across a number of developing countries. 


\section{References}

Abdo, H., \& Aldrugi, A. (2012). Do companies' characteristics play key roles in the level of their environmental disclosures? Energy Research Journal, 3(1), 1-11. https://doi.org/10.3844/erjsp.2012.1.11

Abukari, A. J. \& Abdul-Hamid, I. K. (2018). Corporate social responsibility reporting in the telecommunications sector in Ghana. International Journal of Corporate Social Responsibility, 3(2), 2-9.

Adnan, S.M., Van Staden, C., \& Hay, D. (2010). Do culture and governance structure influence CSR reporting quality: Evidence from China, India, Malaysia and the United Kingdom. In: Sixth Asia Pacific Interdisciplinary Research in Accounting Conference, Sydney, Australia, 12-13 July 2010, pp: 1-27.

Ahmad, Z., Hassan, S. \& Mohammad, J. (2003). Determinants of environmental reporting in Malaysia. International Journal of Business Studies, 11(1), 69-90.

Al-Hamadeen, R. \& Badran, S. (2014). Nature and determinants of CSR Disclosure: Experience of the Jordanian Public Shareholding Companies. European Journal of Business and Management. 6(13), 18-34.

Ali, W. \& Rizwan, M. (2013), "Factors influencing corporate social and environmental disclosure (CSED) practices in the developing countries: an institutional theoretical perspective”, International Journal of Asian Social Science, 3(3), 590-609.

Akbas, E.K. (2012). A sociological study of corporate social responsibility: A Marxist perspective. MSc Thesis, Middle East Technical University, Ankara, Turkey.

Asaolu, T.O., Agboola, A.A., Ayoola, T.J., \& Salawu, M.K. (2011). Sustainability reporting in the Nigerian oil and gas sector. In: Environmental Management Conference, Federal University of Agriculture, Abeokuta, Nigeria, 12-15 September 2011, pp: 1-24.

Ashwin, M. (Ed.) (2011), Proceedings of the 10th European Conference on Research Methodology for Business and Management Studies, Normandy Business School, Caen, 20-21, June.

Bebbington, A., Bebbington, D. H., Bury, J., Lingan, J., Munoz, J. P., \& Scurrah, M. (2008). Mining and social movements: Struggles over livelihood and ruralterritorial development in the Andes. World Development, 36(12), 2888-2905. https://doi.org/10.1016/j.worlddev.2007.11.016

Beddewela, E. \& Herzig, C. (2013), “Corporate social reporting by MNCs’ subsidiaries in Sri Lanka”, Accounting Forum, 37(2), 135-149. https://doi.org/10.1016/j.accfor.2012.09.001

Belal, A. R. (2001) A study of corporate social disclosure in Bangladesh. Managerial Auditing Journal, 16(5), 274-289.

Belal, A.R., Cooper, S.M. \& Roberts, R.W. (2013), "Vulnerable and exploitable: the need for organisational accountability and transparency in emerging and less developed economies”, Accounting Forum, 37(2), 81-91. https://doi.org/10.1016/j.accfor.2013.04.001

Blanc, R., Islam, M. A., Patten, D.M., \& Branco, M.C. (2017). Corporate anti-corruption disclosure: An examination of the impact of media exposure and country-level press freedom, Accounting, Auditing \& Accountability Journal, 30(8), 1746-1770. https://doi.org/10.1108/AAAJ-02-2015-1965 
Botshabelo, I., Mbekomize, C.J. \& Phatshwane, P.M.D. (2017). Corporate Social Responsibility Reporting in Banking Industry: An analysis of disclosure levels in Botswana. International Journal of Business and Management, 12(12), 224-241. https://doi.org/10.5539/ijbm.v12n12p224

Branco, M.C.; Rodrigues, L.L. (2006). Communication of corporate social responsibility by Portuguese banks: A legitimacy theory perspective. Corporate Communications: An International Journal, 11(3), 1356-3289. https://doi.org/10.1108/13563280610680821

Buccina, S., Chene, D. \& Gramlich, J. (2013), “Accounting for the environmental impacts of Texaco's operations in Ecuador: chevron’s contingent environmental liability disclosures”, Accounting Forum, 37(2), 110-123. https://doi.org/10.1016/j.accfor.2013.04.003

Catchpowle, L., \& Smytha. S. (2016). Accounting and social movements: An exploration of critical accounting praxis. Accounting Forum, 40(3), 220-234. https://doi.org/10.1016/j.accfor.2016.05.001

Cho, C. H. (2009). Legitimation strategies used in response to environmental disaster: A French case study of Total S.A.'s Erika and AZF incidents. European Accounting Review, 18(1), 33-62. https://doi.org/10.1080/09638180802579616

Cho, C., Michelon, G., Patten, D. \& Roberts, R. (2015). CSR disclosure: The more things change ...? Accounting, Auditing \& Accountability Journal, 28(1), 14-35.

Chousa, J.P., González, M.V., Cabarcos, M.A.L., \& Castro, N. R. (2017). Managing Reputational Risk through Environmental Management and Reporting: An Options Theory Approach. Sustainability, 9,(376), 2-15. https://doi.org/10.3390/su9030376

Cormier, D., Magnan, M., \& Velthoven, B.V. (2005). Environmental disclosure quality in large German companies: economic incentives, public pressures or institutional conditions? European Accounting Review, 14(1), 3-39. https://doi.org/10.1080/0963818042000339617

Cotter, J., Lokman, N. \& Najah, M. M. (2011). Voluntary disclosure research: Which theory is relevant? Retrieved from: https://www.researchgate.net/.../281390648_Voluntary_disclosure_research_Which_the.. [Accessed: January $15^{\text {th }}, 2018$ ].

Cowan, S., \& Gadenne, D. (2005). Australian corporate environmental reporting: A comparative analysis of disclosure practices across voluntary and mandatory disclosure systems. Journal of Accounting \& Organizational Change, 1(2), 165-179. https://doi.org/10.1108/18325910510635344

Cunha, D. R. \& Moneva, J. M. (2016). Environmental reporting of global oil companies. International Research Journal of Finance and Economics, Issue 158, 84-99.

Cunningham, S. (2001). Theoretical perspectives of corporate environmental disclosures in annual reports. Working paper, Faculty of Business and Law, Central Queensland University, Australia.

Djajadikerta, H. G.,\& Trireksani, T. (2012). Corporate social and environmental disclosure by Indonesian listed companies on their corporate web sites. Journal of Applied Accounting Research, 13(1), 21-36. https://doi.org/10.1108/09675421211231899

Douglas, A., Doris, J., \& Johnson, B. (2004). Corporate social reporting in Irish financial institutions. The TQZ Magazine 16(6), 387-395. https://doi.org/10.1108/09544780410563301 
Eljayash, K. M., Kavanagh, M. \& Kong, E. (2013). Environmental disclosure practices in national oil and gas corporations and international oil and gas corporations operating in organization of Arab petroleum exporting countries. International Journal of Business, Economics and Law, 2(1) 35-52.

Fu, R., Kraft, A., \& Zhang, H. (2012). Financial reporting frequency, information asymmetry, and the cost of equity. Journal of Accounting and Economics, 54(2), 132-149. https://doi.org/10.1016/j.jacceco.2012.07.003

Gallhofer, S., \& Haslam, J. (2003). Accounting and emancipation: Some critical interventions. London: Routledge.

Gherardi, L., Guthrie, J., \& Farneti, F. (2014). Stand-alone sustainability reporting and the use of GRI in Italian Vodafone: A longitudinal analysis. Procedia-Social and Behavioral Sciences, 164, 11-25.

Gugler, P. \& Shi, J.Y.J. (2009). Corporate social responsibility for developing country multinational corporations: lost war in pertaining global competitiveness? Journal of Business Ethics, 87, 3-24. https://doi.org/10.1007/s10551-008-9801-5

Guthrie, J., \& Abeysekera, I. (2006). Content analysis of social, environmental reporting: what is new? Journal of Human Resource Costing \& Accounting, 10(2), 114-126. https://doi.org/10.1108/14013380610703120

Habek, P. \& Wolniak, R. (2016). Assessing the quality of corporate social responsibility reports: the case of reporting practices in selected European Union member states. Quality Quantity, 50(1), 399-420. https://doi.org/10.1007/s11135-014-0155-z

Hackston, D., \& Milne, M. (1996). Some determinants of social and environmental disclosures in New Zealand companies. Accounting, Auditing \& Accountability Journal, 9(1), 77108. https://doi.org/10.1108/09513579610109987

Hartviksen, J. (2014). Towards a historical materialist analysis of femicide in postconflict Guatemala, Master of Arts in Global Development, Queen’s University, Kingston, Ontario. Canada.

Hassan, N. T. (2014). Corporate Governance, Degree of Multi-nationality, and Corporate Social Responsibility Disclosure: Evidence from the UK. Journal of Empirical Research in Accounting \& Auditing,1(1), 75-98.

Hassan, N. T. (2010). Corporate social responsibility disclosure: An examination of framework of determinants and consequences. PhD Thesis, Durham University, Durham, UK.

Harvey, D. (2003). The new imperialism. Oxford: Oxford University Press.

Hilson, G. (2012). Corporate Social Responsibility in the extractive industries: Experiences from developing countries. Resources Policy, 37(2), 131-137. https://doi.org/10.1016/j.resourpol.2012.01.002.

Hooks, J.,\& Van Staden, C.J. (2011). Evaluating environmental disclosures: the relationship between quality and extent measures. British Accounting Review, 43(3), 200-213. https://doi.org/10.1016/j.bar.2011.06.005

Idowu, S. O., \& Papasolomou, I. (2007). Are the corporate social responsibility matters based on good intentions or false pretences? An empirical study of the motivations behind the issuing of CSR reports by UK companies. Corporate Governance, 7(2), 136147. https://doi:10.1108/14720700710739787. 
Idowu, S. O. \& Towler, B. (2004). A comparative study of the contents of corporate social responsibility reports of UK companies. Management of Environmental Quality: An International Journal, vol. 15, no. 4, pp. 420-437. https://doi.org/10.1108/14777830410540153

Islam, M.A. \& Deegan, C. (2008). Motivations for an organization within a developing country to report social responsibility information: evidence from Bangladesh. Accounting, Auditing and Accountability Journal, 21, 850-874.

Islam, S., Hosen, A., \& Islam, M. (2005). An examination of corporate environmental disclosure by the Bangladeshi public limited companies. Pakistan Journal of Social Science, 3, 1095-1102.

Islam, J., Prihatiningtias, Y., Ali, Q., \& Yuhariprasetia, Y. (2011). Corporate social responsibility reporting practices: A comparative study between Australia and Indonesia. Retrieved from www.wbiconpro.com/307-Jesmin.pdf [Accessed: $3^{\text {rd }}$ May, 2012].

Islam, M.A. (2015), Social Compliance Accounting: Managing Legitimacy in Global Supply Chains: CSR, Sustainability, Ethics \& Governance, Springer, Switzerland. https://doi.org/10.1007/978-3-319-09997-2

Jamali, D., \& Karam, C. (2018). Corporate social responsibility in developing countries as an emerging field of study. International Journal of Management Reviews, 20(1), 32-61. https://doi.org/10.1111/ijmr.12112

James, R.A. (2011) Strategic alliances between national and international oil companies. Freeman Spogli Institute for International Studies. Working Paper No. 104. Retrieved from https://pesd.fsi.stanford.edu/.../WP_104\%2C_James\%2C_NOCIOC_Stategic_Alliance. [Accessed: 5 ${ }^{\text {th }}$ July, 2017].

Jenkins, H., \& Yakovleva, N. (2006). Corporate social responsibility in the mining industry: Exploring trends in social and environmental disclosure. Journal of Cleaner Production, 14(3/4), 271-284. https://doi.org/10.1016/j.jclepro.2004.10.004

Jitaree, W. (2015). Corporate Social Responsibility Disclosure and Financial Performance: Evidence from Thailand. PhD Thesis, University of Wollongong, Australia.

Kamal, Y., \& Deegan, C. (2013). Corporate social and environmental-related governance disclosure practices in the textile and garments industry; Evidence from a developing country. Australian Accounting Review, 23(2/65), 117-134. https://doi.org/10.1111/j.1835-2561.2012.00205.x

Kanter, R. M. (2011). How great companies think differently. Harvard Business Review, 89(11), 66-78.

Keshishian, F. (2015). Culture, economics, and business ethics as a core course: A synthesis from a historical materialist perspective. Proceedings of the $22^{\text {nd }}$ International Vincentian Business Ethics Conference, New York, USA, October 22-24.

Kolk, A. (2004), A decade of sustainability reporting, development and significance. International Journal of Environment and Sustainable Development, vol. 3, no. 1, pp. 51-64. https://doi.org/10.1504/IJESD.2004.004688

Lash, S., \& Urry, J. (1987).The End of Organized Capitalism (Cambridge: Polity Press).

Legendre, S. \& Coderre, F. (2013). Determinants of GRI G3 application levels: the case of the Fortune Global 500. Corporate Social Responsibility and Environmental Management, 20(3), 182-192. https://doi: 10.1002/csr.1285

Levine, A.,\& Sober, E. (1985). What's historical about historical materialism? The Journal of Philosophy, 82(6), 304-326. https://doi.org/10.2307/2026564 
Marx, K.,\& Engels, F. (1970).German Ideology, International Publishers Co.

Matuszak, L. \& Rózańska, E. (2017). CSR Disclosure in Polish-Listed Companies in the Light of Directive 2014/95/EU Requirements: Empirical Evidence. Economic, Business and Management Aspects of Sustainability, 9(12). 2-18.

Mbekomize, C. J., \& Wally-Dima, L. (2013). Social and environmental disclosure by parastatals and companies listed on the Botswana Stock Exchange. Journal of Management \& Sustainability, 3(3), 66-75. https://doi.org/10.5539/jms.v3n3p66

Mitchell, J., Percy, M., \& McKinlay, B. (2006). Voluntary environmental reporting practices: A further study of “poor” environmental performers. Australian Journal of Corporate Law, 19(2), 182-215.

Momin, M.A. \& Parker, L.D. (2013), “Motivations for corporate social responsibility Reporting by MNC subsidiaries in an emerging country: the case of Bangladesh”, British Accounting Review, 45, 215-228.

Narwal, M., \& Singh, R. (2013). Corporate social responsibility practices in India: A comparative study of MNCs and Indian companies. Social Responsibility Journal, 9(3), 465 - 478. https://doi.org/10.1108/SRJ-11-2011-0100

Novelini, C. P., \& Fregonesi, M. S. F. A. (2013). Analysis of information disclosure about social investments by companies that declare themselves socially responsible. Journal of Accounting \& Organizations, 17, 86-97. https://doi.org/10.11606/rco.v7i17.56695

Nwobu, O. A. (2017). Determinants of Corporate Sustainability Reporting in Selected Companies in Nigeria. PhD Thesis, Covenant University, Nigeria.

Odera, O., Scott, A., \& Gow, J. (2016). Differential reporting of social and environmental disclosures between local and foreign oil companies in Nigeria. Social Responsibility Journal, 12(3), 415-438.

Okoro, O. (2014). Corporate Social Responsibility Agenda for International Oil Companies (IOCs): New Perspectives from Stakeholders in the Niger Delta Region (NDR) of Nigeria. PhD Thesis, Auckland University of Technology, New Zealand.

Ong, S.H. (2016). Measuring the quality and identifying influencing factors of sustainability reporting: Evidence from the resources industry in Australia. PhD Thesis, Edith Cowan University, Australia.

Patten, D. (1992). Intra-industry environmental disclosures in response to the Alaskan oil spill: A note on legitimacy theory. Accounting, Organizations and Society,17(5), 471475. https://doi.org/10.1016/0361-3682(92)90042-Q

Pepper, D. (1996).'Radical materialism: changing the economic base'. In Modern Environmentalism: An introduction, pp. 301-305. Routledge.

Pesci, C., \& Costa, E. (2014). Content analysis of social and environmental reports of Italian cooperative banks: Methodological issues. Retrieved from www.tandfonline.com/doi/pdf/10.1080/0969160X.2014.904239 [Accessed: $15^{\text {th }}$ April, 2014]. https://doi.org/10.1080/0969160X.2014.904239

Peters, G.F., \& Romi, A.M. (2015). The association between sustainability governance characteristics and the assurance of corporate sustainability reports. Auditing: A Journal of Practice \& Theory, 34(1), 163-198.

Plumlee, M., Brown, D., Hayes, R. M., \& Marshall, R. S. (2010). Voluntary environmental disclosure quality and firm value: Further evidence. University of Utah and Portland State University, USA. 
Rahma, D., \& Anis, J. (2013). Social disclosure: What are the main explanatory factors? An empirical test in the Tunisian context. International Journal of Accounting \& Economics Studies, 2(1), 34-39. https://doi.org/10.14419/ijaes.v2i1.1505

Sahore, N.S. \& Verma, A. (2017). Environmental Disclosures and Size of Selected Indian Firms European Scientific Journal, 13, 515-529.

Saleh, M. (2009). Corporate Social Responsibility Disclosure in an Emerging Market: A Longitudinal Analysis Approach. Business Research, 2(1), 131-141. https://doi.org/10.5539/ibr.v2n1p131

Sen, M., Mukherjee, K., \& Pattanayak, J. K. (2011). Corporate environmental disclosure practices in India. Journal of Applied Accounting Research, 12(2), 139-156. https://doi.org/10.1108/09675421111160709

Shayuti, M.A. (2012), Culture and Corporate Social Responsibility (CSR) reporting: evidence from China, India, Malaysia and United Kingdom. PhD Thesis, University of Auckland, New Zealand.

Singh, P.J., Sethuraman, K. \& Lam, J.Y. (2017) Impact of Corporate Social Responsibility Dimensions on Firm Value: Some Evidence from Hong Kong and China. Sustainability Journal, 9, (1532), 5-24. https://doi.org/10.3390/su9091532

Smith, K.T. \& Alexander, J. (2013). Which CSR-related Headings Do Fortune 500 Companies Use on Their Websites? Business and Professional Communication Quarterly (formerly Business Communication Quarterly), 76(2), 155-171. https://doi.org/10.1177/1080569912471185

Soobaroyen, T. \& Mahadeo, J.D. (2016). Community disclosures in a developing country: insights from a neo-pluralist perspective. Accounting, Auditing \& Accountability Journal, 29(3), 452-482.

Soobaroyen, T. \& Ntim, C.G. (2013), "Social and environmental accounting as symbolic and substantive means of legitimation: the case of HIV/AIDS reporting in South Africa”, Accounting Forum, 37(2), 92-109.

Talebnia, G., Vakilifard, H., Yaghoubnezhad, A., \& Alikhani, R. (2013). Corporate social and environmental disclosure in developing countries: Evidence from Iran. Management Science Letters, 3, 135-146.

Thompson, P. and Zakarai (2004). Corporate Social Responsibility Reporting in Malaysia. Journal of Corporate Citizenship, 13, 125 - 136. https://doi.org/10.9774/GLEAF.4700.2004.sp.000014

Thoradeniya P., Lee, J., Tan, R., \& Ferreira, A. (2015). Sustainability reporting and the theory of planned behavior. Accounting, Auditing \& Accountability Journal, 28(7), 1099 - 1137. https://doi.org/10.1108/AAAJ-08-2013-1449

Uwalomwa, U., \& Jimoh, J. (2012). Corporate environmental disclosures in the Nigerian manufacturing industry: A study of selected firms. African Research Review, 6(3), 71-83. https://doi.org/10.4314/afrrev.v6i3.5

Van de Burgwal, D., \& Vieira, R. J. O. (2014). Environmental disclosure determinants in Dutch listed companies. Retrieved from www.scielo.br/scielo.php?pid=S151970772014000100006...sci... [Accessed: $15^{\text {th }}$ April, 2014].

Van Staden, C.J., \& Hooks, J. (2007).A comprehensive comparison of corporate environmental reporting and responsiveness, British Accounting Review, Vol. 39 No. 3, pp. 197-210. https://doi.org/10.1016/j.bar.2007.05.004 
Virtania, L.O. \& Siregar, S.V. (2017). The Effect of Environmental Disclosure on Cost of Equity. Advances in Economics, Business and Management Research, 36, 95- 104. https://doi.org/10.2991/icbmr-17.2017.9

Welbeck, E.E. (2017) "The influence of institutional environment on corporate responsibility disclosures in Ghana", Meditari Accountancy Research, 25(2), 216-240. https://doi.org/10.1108/MEDAR-11-2016-0092

Zunker, T. (2011). Determinants of the voluntary disclosure of employee information in annual reports: An application of Stakeholder Theory, PhD Thesis, Bond University, Queensland, Australia. 